\title{
NUMBER OF CONFIRMED CASES OF VIRAL HEPATITIS IN BRAZIL BETWEEN 2010 AND 2015
}

\section{ORIGINAL ARTICLE}

NUNES, Filipe Sales', FACCO, Lucas², FECURY, Amanda Alves³, ARAÚJO, Maria Helena Mendonça de ${ }^{4}$, OLIVEIRA, Euzébio de ${ }^{5}$, DENDASCK, Carla Viana ${ }^{6}$, SOUZA, Keulle Oliveira da ${ }^{7}$, DIAS, Claudio Alberto Gellis de Mattos ${ }^{8}$

NUNES, Filipe Sales. Et al. Number of confirmed cases of viral hepatitis in Brazil between 2010 and 2015. Revista Científica Multidisciplinar Núcleo do Conhecimento. Year 05, Ed. 11, Vol. 25, pp. 71-80. November 2020. ISSN:24480959, Access link in: https://www.nucleodoconhecimento.com.br/health/viralhepatitis, DOI: 10.32749/nucleodoconhecimento.com.br/health/viral-hepatitis

\section{ABSTRACT}

Viral hepatitis is an infectious disease that attacks the liver, and its causative agents are viruses. This work aims to demonstrate the number of confirmed cases of viral hepitis in Brazil between the years 2010 and 2015. A survey was carried out in the DATASUS database on the website (http://datasus.saude.gov. br /). Hepatitis represents a vast public health problem in Brazil. Of those infected, a large portion is composed of male individuals, with the visible lower demand for health services an important factor for this finding. Hepatitis $\mathrm{B}$ and $\mathrm{C}$ are the most common among viral

\footnotetext{
${ }^{1}$ Computer Network Technician, graduated from the Federal Institute of Amapá (IFAP).

${ }^{2}$ Student of the Medical Course at the Federal University of Amapá (UNIFAP).

${ }^{3}$ Biomedical, PhD in Tropical Diseases, Professor and researcher of the Course of Medicine at the Federal University of Amapá (UNIFAP).

${ }^{4}$ Physician, Professor and researcher of the Medicine Course at the Federal University of Amapá (UNIFAP).

${ }^{5}$ Biologist, Doctor in Topical Diseases, Professor and researcher of the Physical Education Course at the Federal University of Pará (UFPA).

${ }^{6}$ Theologian, PhD in Psychoanalysis, researcher at the Research and Studies Center Advanced - CEPA.

${ }^{7}$ Sociologist, Master's student in Anthropic Studies in the Amazon, Member of the Research Group "Laboratory of Education, Environment and Health" (LEMAS / UFPA).

${ }^{8}$ Biologist, PhD in Theory and Research of Behavior, Professor and researcher of the Graduate Program in Professional and Technological Education (PROFEPT), Federal Institute of Amapá (IFAP).
}

RC: 66674

Available in: https://www.nucleodoconhecimento.com.br/health/viral-hepatitis 
hepatitis and one of the important factors that contribute to the rate of infection by the hepatitis viruses is their co-infection with HIV. Laboratory tests (immunoassay, molecular test) must be performed to detect markers and determine the etiologic agent that causes the pathology.

Keywords: Epidemiology, virus, hepatitis.

\section{INTRODUCTION}

Viral hepatitis is an infectious disease that attacks the liver. They are considered a public health problem in Brazil due to their large number of confirmed cases (MARGREITER et al., 2015; LEITE, et al., 2020).

The etiologic agents discovered from viral hepatitis are the VHA, HBV, HCV, VHD and HEV viruses, which have in common the ease of binding with liver cells. There are differences in their clinical form and epidemiological characteristics (NUNES et al., 2016).

Hepatitis $\mathrm{A}(\mathrm{VHA})$ and $\mathrm{E}(\mathrm{HEV})$ have their viruses transmitted via the fecal-oral route, which can be found in contaminated water and food. The lack of proper treatment of the water consumed and the improper handling of food are the main factors in the spread of the virus. When the disease presents symptoms, it can cause a decrease in appetite, fever and changes in the color of the contaminated individual's urine (MOCBEL et al., 2016).

The hepatitis A virus has an effective vaccine, considered safe, and can maintain immunity that varies from 5 to 10 years. The vaccine is divided into two doses and can be applied to children from the first year of age (FERREIRA et al., 2014). Hepatitis E has a vaccine, but not on a global scale. Initially marketed in 2012 and produced in China, it is already considered effective (NUNES et al., 2016).

The hepatitis $\mathrm{C}$ virus $(\mathrm{HCV})$ is transmitted mainly by blood transfusion, and also by sexual intercourse, congenital form, and sharing sharps or personal hygiene.

RC: 66674

Available in: https://www.nucleodoconhecimento.com.br/health/viral-hepatitis 
Hepatitis $\mathrm{C}$ has a more complicated diagnosis due to the complexity of its virus. In less than half of the cases it is not possible to identify the mechanical source of the infection. Most cases of hepatitis $C$ reach chronic form without presenting symptoms. They usually appear only after years of infection when individuals are at a more severe stage. The minority of cases usually progress to liver cirrhosis or liver cancer (GUSMÃO et al., 2017).

Treatment varies according to and genotype of the virus, using drugs to prevent its reproduction, thus reducing the worsening of the infection. The duration of treatment can be from 48 to 72 weeks, where there can be a huge decrease in the viral load in the patient, but not a total extinction of the virus (SILVA et al., 2014). A vaccine against the hepatitis $C$ virus has not yet been developed. One way to prevent the spread of the virus is to mobilize risk groups, such as drug users and health professionals (GUSMÃO et al., 2017).

Hepatitis B (HBV) has its virus transmitted vertically, passed from mother to child at the time of delivery or breastfeeding. Also by sharing sharps like needles and pliers, blood transfusion and sexual form (FRANCISCO et al., 2015).

Hepatitis B and D can present in two clinical forms: acute and chronic. When they have symptoms, they are identical, such as physical malaise; changes in urine color; feces; yellowing of the skin and eyes (BRASIL, 2014; BRASIL, 2014a).

The hepatitis D virus (HDV), directly needs the hepatitis B virus (HBV) to be infectious, so the means of transmission are the same, since it is not possible for an individual to be infected with HDV without the HBV. The hepatitis B virus vaccine is also effective for immunization against hepatitis $D$, due to the joint infection ratio of the viruses (NUNES et al., 2016).

RC: 66674

Available in: https://www.nucleodoconhecimento.com.br/health/viral-hepatitis 


\section{AIM}

Demonstrate the number of confirmed cases of viral hepatitis in Brazil between the years 2010 and 2015.

\section{METHOD}

A search was carried out in the DATASUS database on the website (http://datasus.saude.gov.br/), from where the data were taken, following the steps: In the website menu, the "Access to information "then the option" Health Information TABNET ", then the option" Epidemiologies and morbidity ". After the page was loaded, the group "Diseases and health problems - From 2007 onwards (SINAN)" was selected. UF and Municipality ". In the column option," Not active "," Sex "," Age group "," Class. Etiological”, "Fonte Mecan Infecção”, "Class. Final "," Clinical Form "," Schooling ". For each item selected in the column, in the line "Year Di-ag / Symptoms", and in the Period, the years 2010 to 2015 were always used. The data was compiled within the Excel application, part of the Office package. Microsoft Corporation. The bibliographic research was carried out on scientific articles, using computers from the computer lab of the Federal Institute of Education, Science and Technology of Amapá, Campus Macapá, located at: Rodovia BR 210 KM 3, s / n Bairro Brasil Novo. CEP: 68.909-398, Macapá, Amapá, Brazil.

\section{RESULTS}

Figure 1 shows the number of confirmed cases of viral hepatitis in Brazil between 2010 and 2015. Between the years 2010 to 2013 the data shows an increase in the number of cases. Between 2013 and 2015 there is a decrease in infections with viral hepatitis.

$\mathrm{RC}: 66674$

Available in: https://www.nucleodoconhecimento.com.br/health/viral-hepatitis 
Figure 1 Number of confirmed cases of viral hepatitis in Brazil between 2010 and 2015.

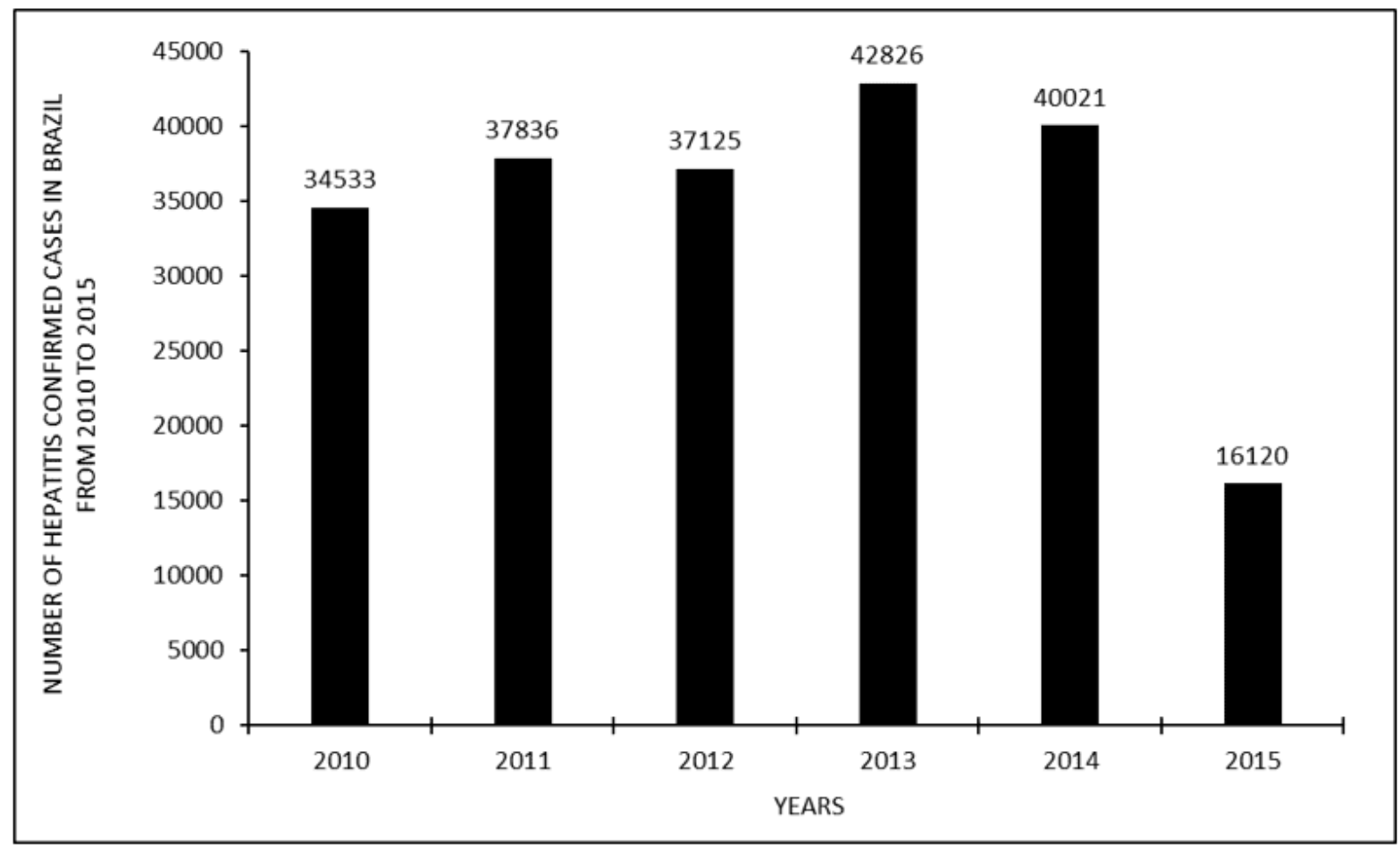

Figure 2 shows the number of confirmed cases of viral hepatitis in Brazil between the years 2010 and 2015 by gender. The data show a greater number of cases among male individuals when compared to the female gender.

$\mathrm{RC}: 66674$

Available in: https://www.nucleodoconhecimento.com.br/health/viral-hepatitis 
Figure 2 Number of confirmed cases of viral hepatitis in Brazil between 2010 and 2015 by gender.

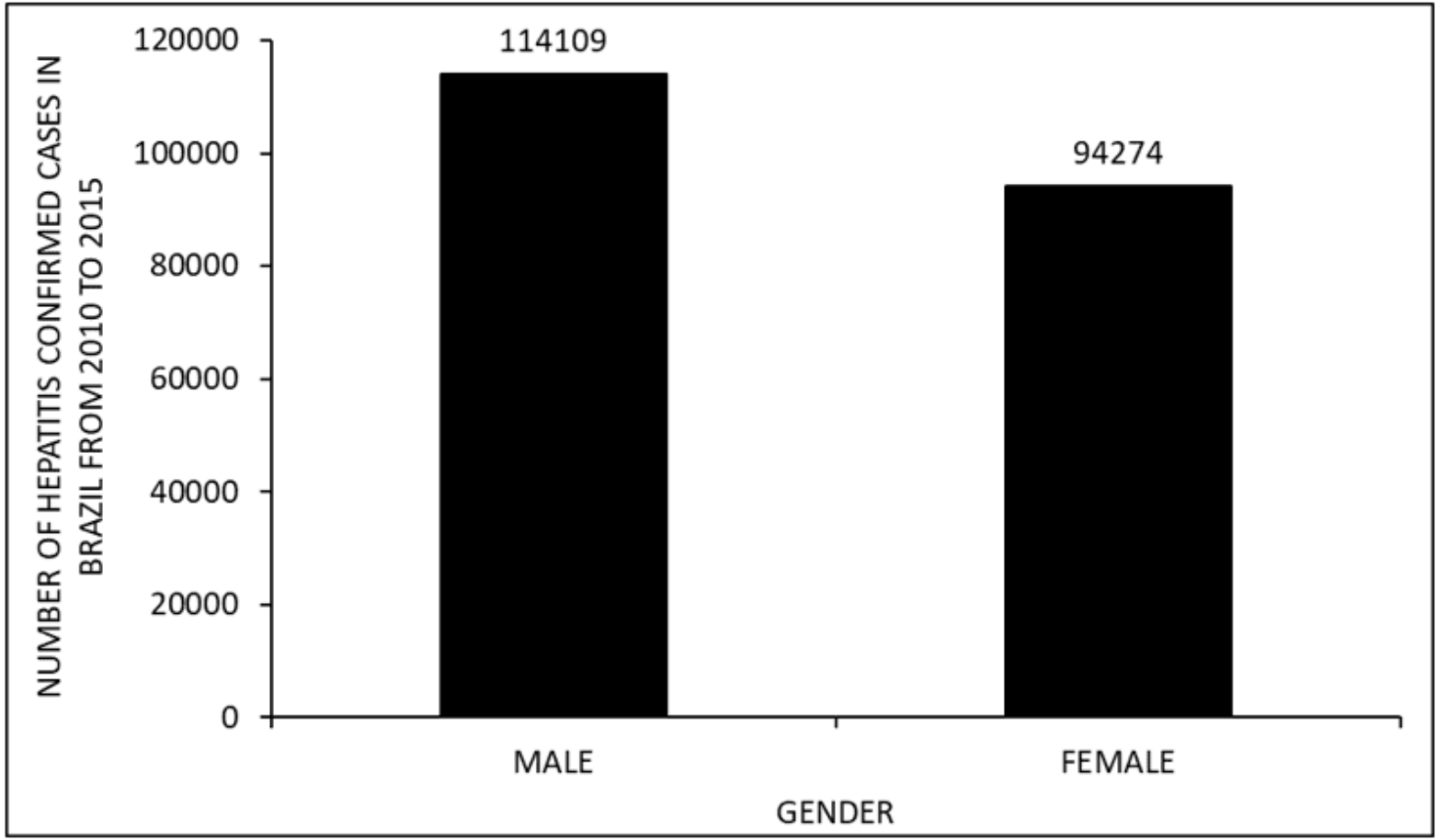

Figure 3 shows the number of confirmed cases of viral hepatitis in Brazil between 2010 and 2015 by age group. The largest number of cases occurs in the age group between 40 and 59 years, and the second largest number between 20 and 39 years.

RC: 66674

Available in: https://www.nucleodoconhecimento.com.br/health/viral-hepatitis 
Figure 3 Number of confirmed cases of viral hepatitis in Brazil between 2010 and 2015 by age group.

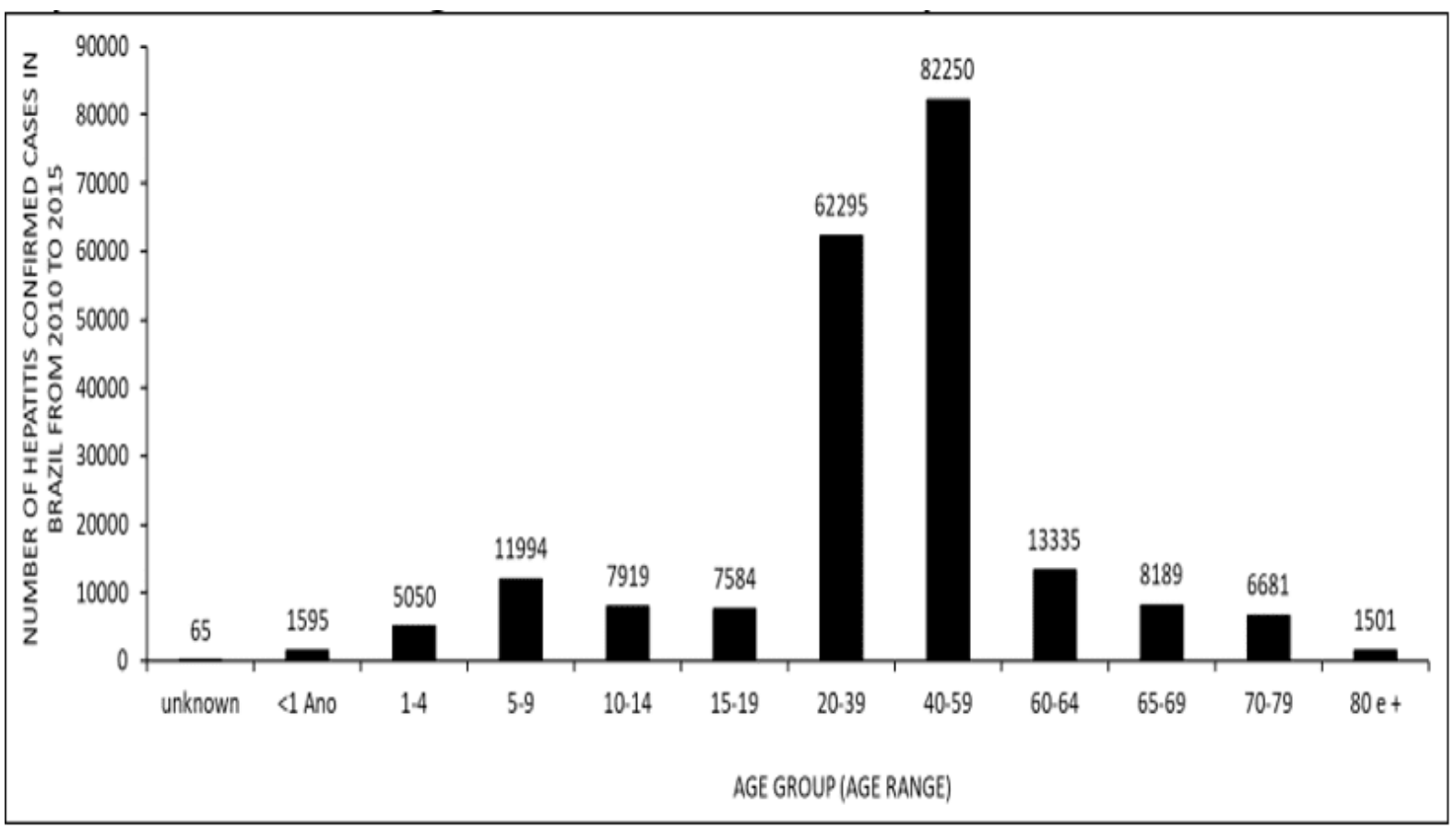

Figure 4 shows the number of confirmed cases of viral hepatitis in Brazil between the years 2010 and 2015 by etiological class, the highest rate of the disease occurs with the presence of virus $C$, the second highest with virus $B$.

RC: 66674

Available in: https://www.nucleodoconhecimento.com.br/health/viral-hepatitis 
Figure 4 Number of confirmed cases of viral hepatitis in Brazil from 2010 to 2015 by etiological class.

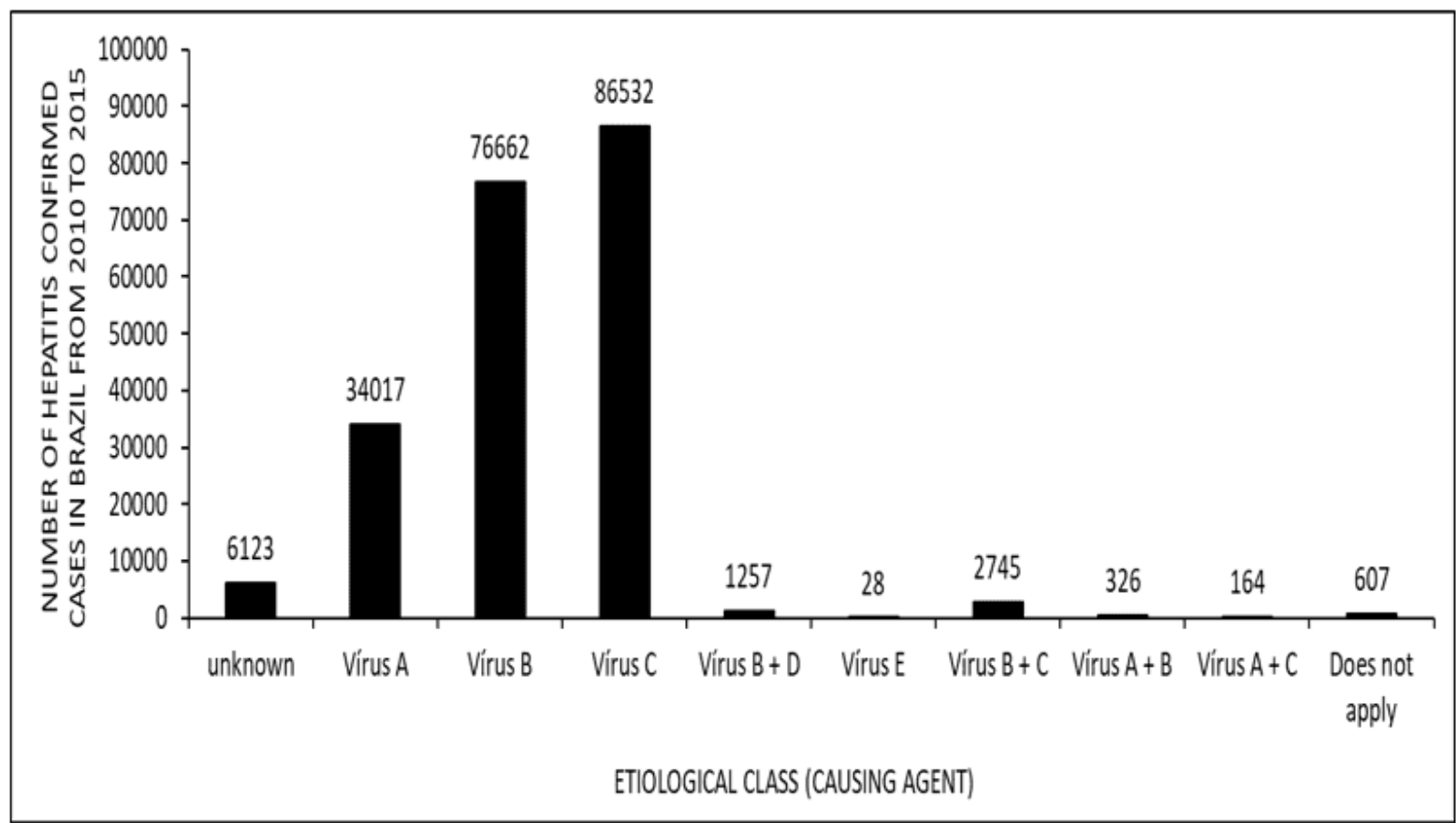

Figure 5 shows the number of confirmed cases of viral hepatitis in Brazil between the years 2010 and 2015 by mechanical source of contamination, demonstrating that the largest number of cases, where the mechanical source is recognized, was due to sexual transmission and in according to Food / Water.

RC: 66674

Available in: https://www.nucleodoconhecimento.com.br/health/viral-hepatitis 
Figure 5 Graph with the number of confirmed cases of viral hepatitis in Brazil from 2010 to 2015 by mechanical source.

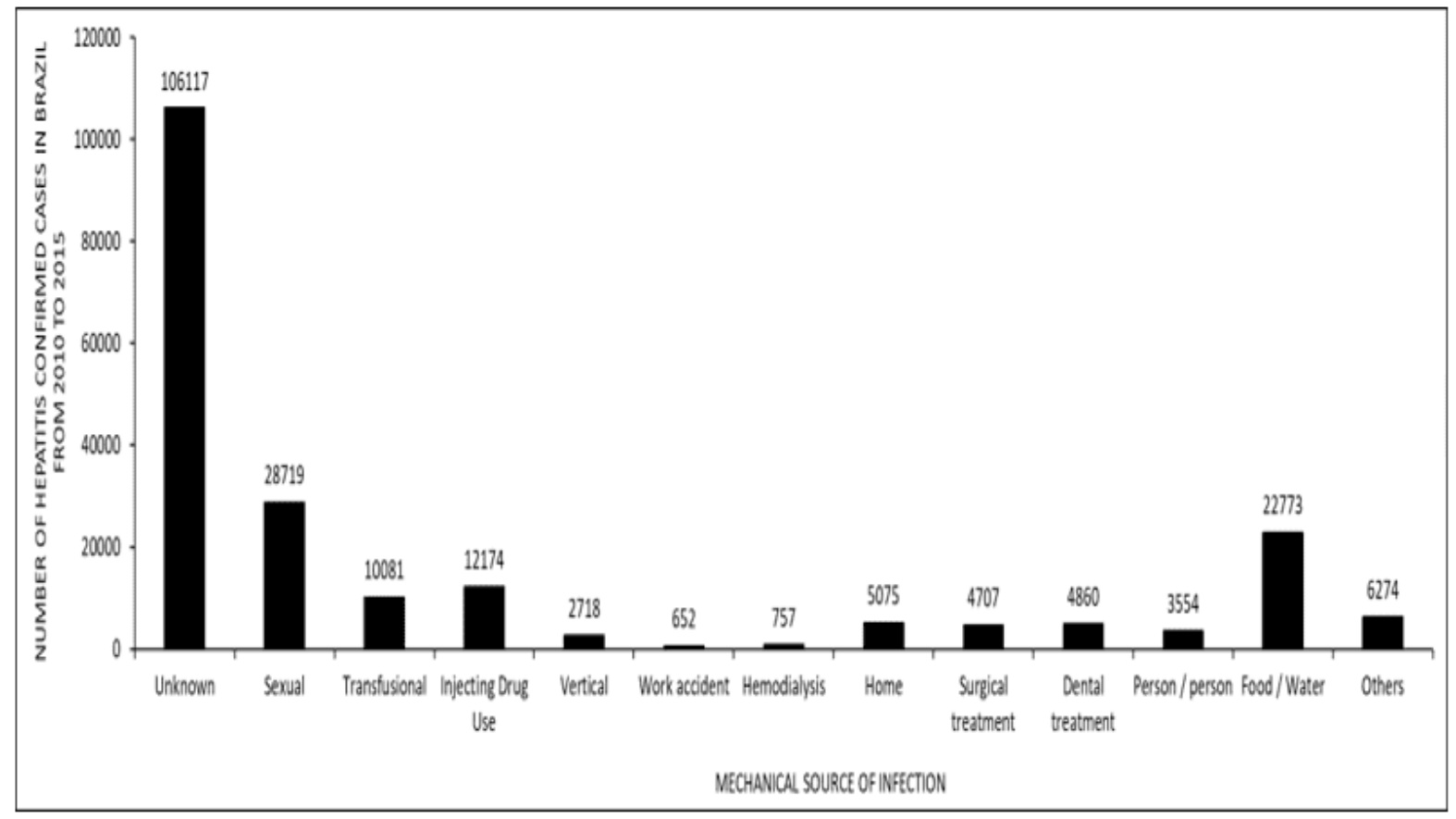

Figure 6 shows the percentage of confirmed cases of viral hepatitis in Brazil between the years 2010 and 2015 by their final classification. It was recorded that the largest percentage of diagnoses were performed in the laboratory.

RC: 66674

Available in: https://www.nucleodoconhecimento.com.br/health/viral-hepatitis 
Figure 6 Graph with percentage of confirmed cases of viral hepatitis in Brazil by final classification between the years 2010 and 2015.

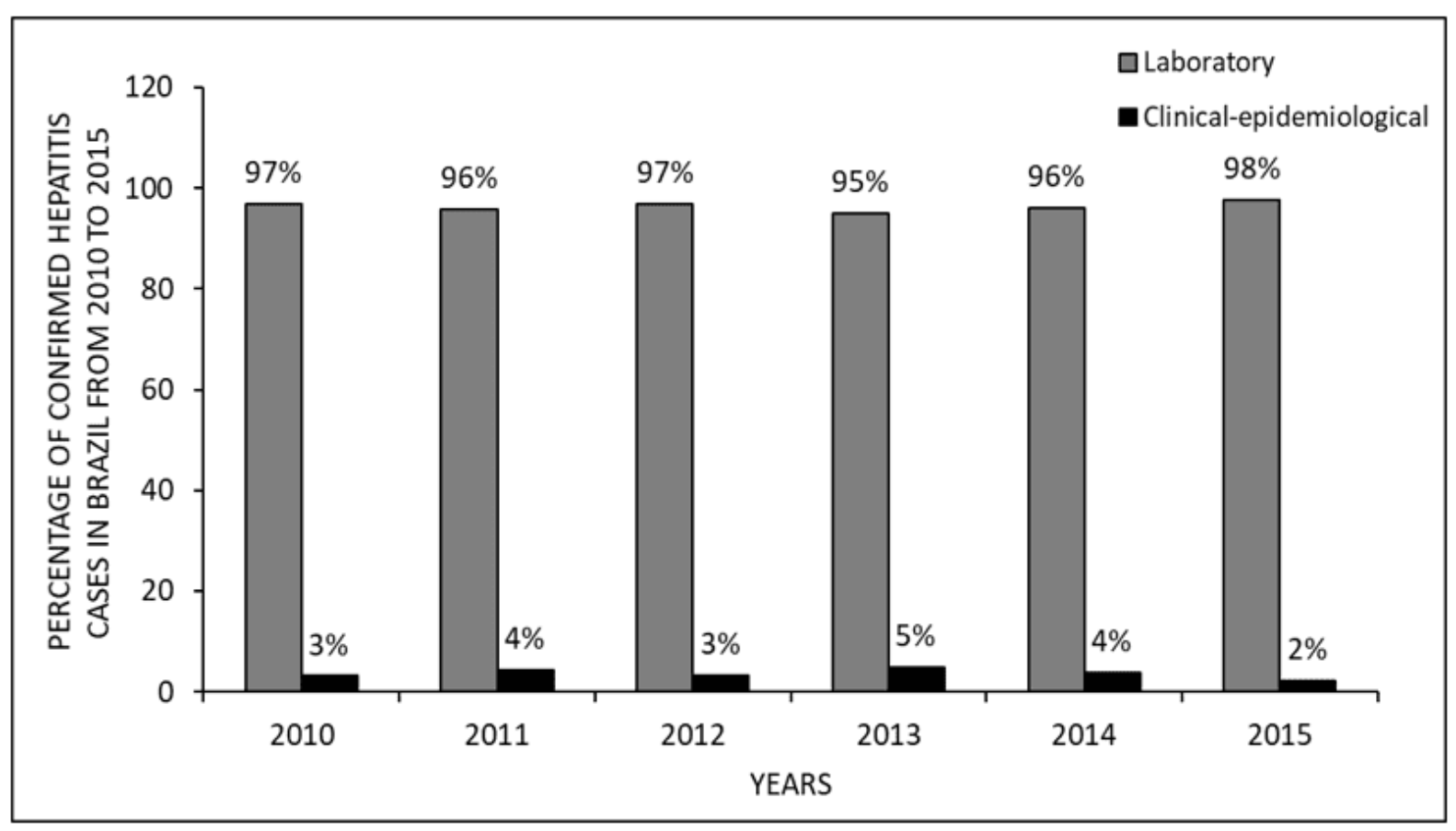

Figure 7 shows the number of confirmed cases of viral hepatitis in Brazil by clinical form between the years 2010 and 2015, showing that the highest incidence is in the form of chronic hepatitis / carrier.

RC: 66674

Available in: https://www.nucleodoconhecimento.com.br/health/viral-hepatitis 
Figure 7 Number of confirmed cases of viral hepatitis in Brazil from 2010 to 2015 by clinical form

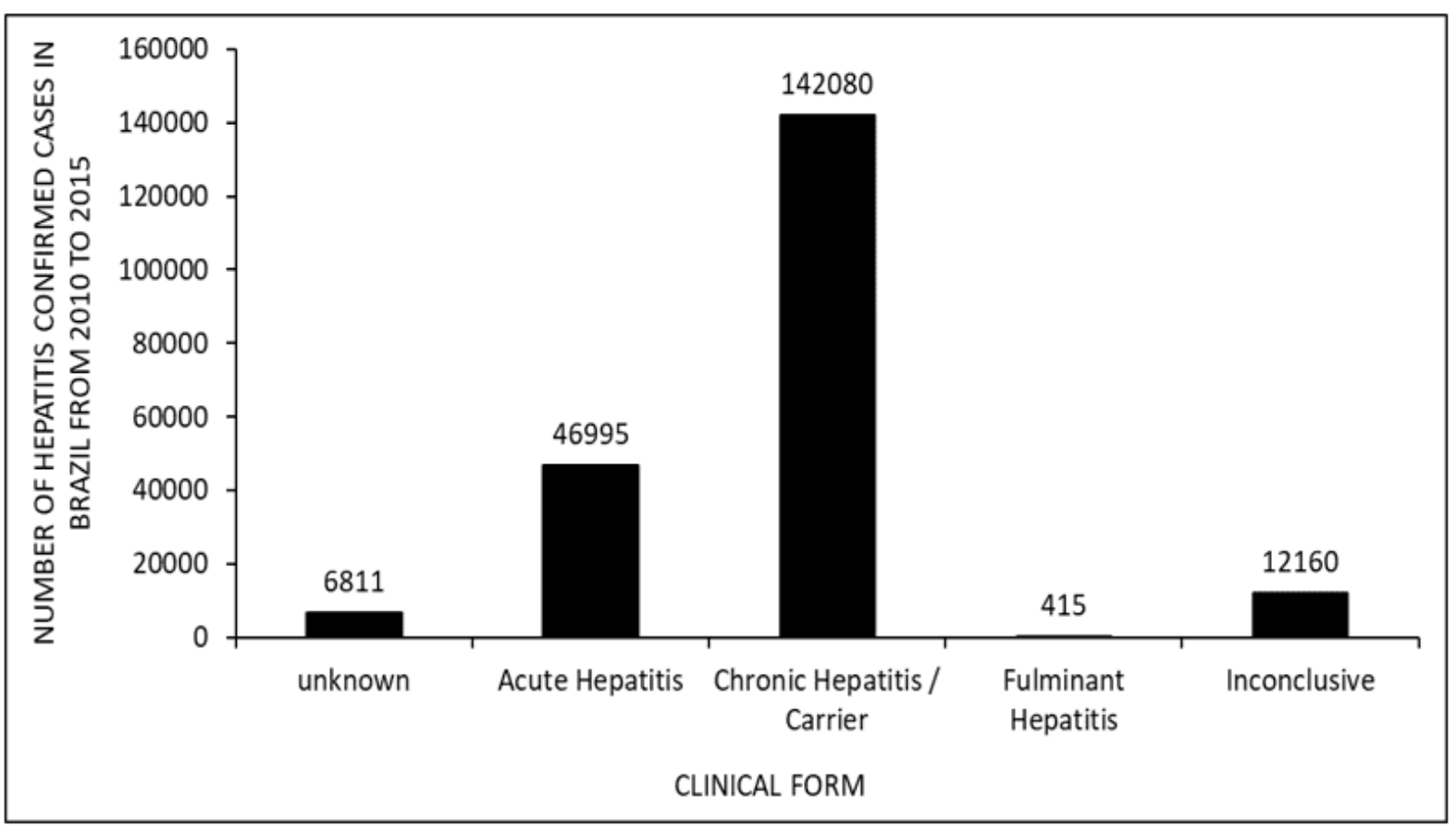

Figure 8 shows the number of confirmed cases of viral hepatitis in Brazil between 2010 and 2015 by the level of education of the infected individuals. Demonstrating that the greatest number of cases, when the individual identifies his education, occurs in people with complete high school and in second with the incomplete 5th to 8th grade of PE.

RC: 66674

Available in: https://www.nucleodoconhecimento.com.br/health/viral-hepatitis 
Figure 8 Number of confirmed cases of viral hepatitis in Brazil between 2010 and 2015 by individuals' education.

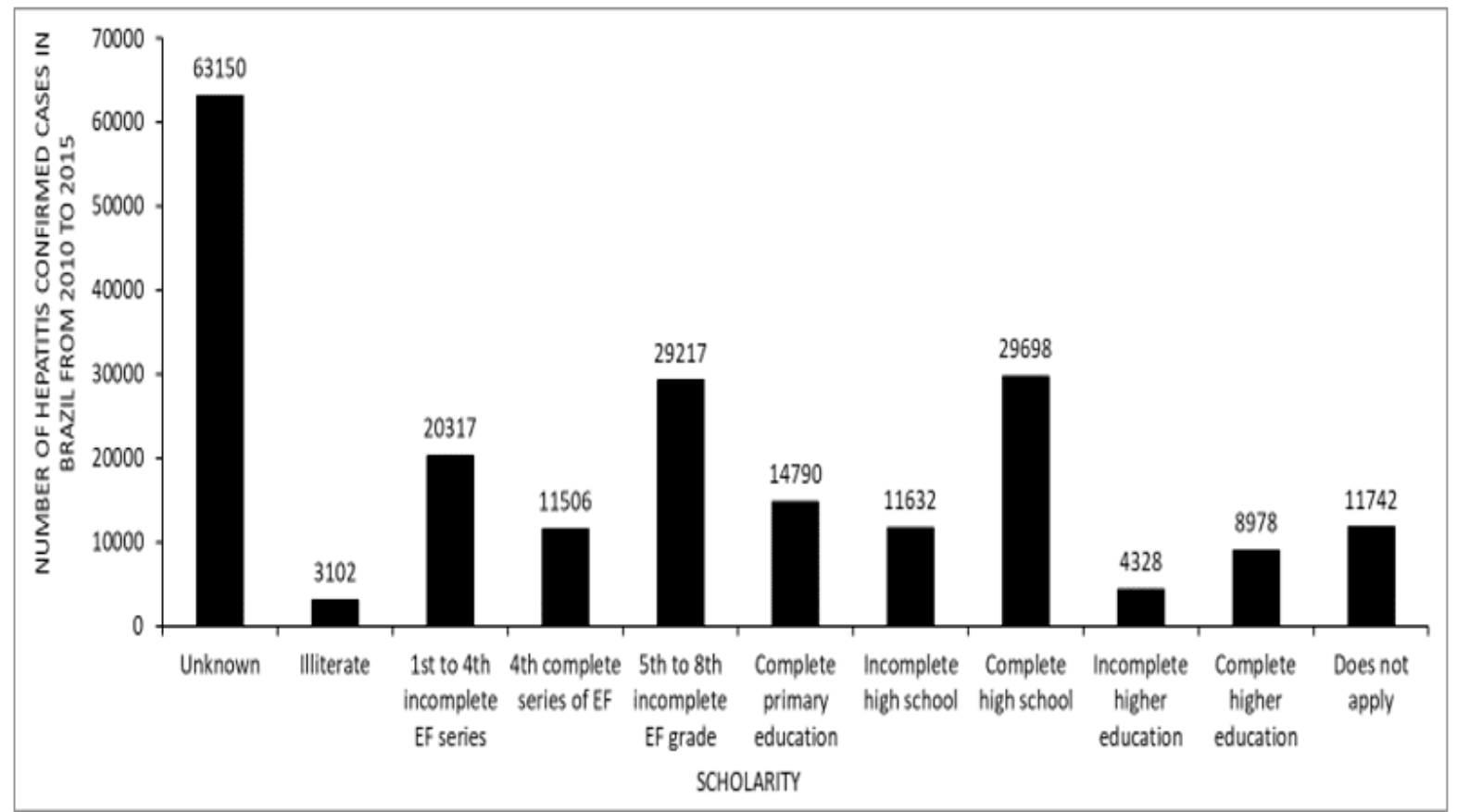

\section{DISCUSSION}

Viral hepatitis is a comprehensive public health problem in Brazil. By taking into account several factors, such as the irregular distribution of health care services and the concomitant inequality of diagnostic technology, in addition to the economic and social disparity, it is possible to understand some of the reasons that are linked to the high numbers of hepatitis in the country. parents. In addition to these, the inaccurate knowledge about the continent of infected people and insufficient education regarding the etiological agents of viral hepatitis and their means of transmission also contribute negatively to the dynamics of the pathology advance in Brazil (FERREIRA and SILVEIRA, 2004).

Among individuals infected by the various viruses that cause hepatitis, the majority are male. Numerous studies indicate that men tend to exercise less demand for medical services in general and, in view of this fact, suffer more deaths due to

RC: 66674

Available in: https://www.nucleodoconhecimento.com.br/health/viral-hepatitis 
chronic diseases (GOMES et al., 2007). Among the main risk groups for hepatitis virus infection, especially HBV, there are: health professionals, people who use intravenous drugs, hemodialysis patients, sex professionals, and individuals male homosexuals (FERREIRA and SILVEIRA, 2004).

Using data from the 2015 Viral Hepatitis Epidemiological Bulletin, it is possible to see the main age ranges in which hepatitis cases predominate. In the case of hepatitis $A$, the infection tends to occur mainly among children under 10 years of age, with the peak occurring between 5 and 6 years. In relation to hepa-titis $B$, the peak of cases occurs in the age range of 20 and 30 years. In hepatitis $C$, it is noted that the highest rate of cases occurs among individuals aged 40 and 60 (BRASIL, 2015). An important observation is the significant increase - $97.7 \%$ - in the transmission of hepatitis $A$ in male individuals, between 20 and 39 years old, through sexual means, according to the Epidemiological Bulletin of Viral Hepatitis of 2018 (BRASIL, 2018a) . The sexual route of transmission of hepatitis $C$ is the subject of debate, as, unlike the recognized potential for sexual transmission of hepatitis $\mathrm{B}, \mathrm{HCV}$ has infectivity through sexual activity that occurs in a limited way and, therefore, is not fact classified as an STI (Sexually Transmitted Infection) (ALMEIDA and MARTINS, 2015).

In Brazil, between 1999 and 2018, there were 632,814 confirmed cases of viral hepatitis. Of these cases, $36.8 \%(233,027)$ are related to hepatitis $B, 36.1 \%$ $(228,695)$ to hepatitis $C$, which represent the highest numbers. Hepatitis A represents $26.4 \%$ of the total $(167,108)$, in addition to $0.7 \%$ of hepatitis $D(3,984)$, the latter being hepatitis with the least number of notifications and a wide difference, in numbers, from the others. Hepatitis C, since 2015, has exceeded the numbers of hepatitis B in incidence rates annually (BRASIL, 2019). One issue to be taken into account is the coinfection by the Human Immunode-deficiency Virus (HIV) and hepatitis B (HBV) and C (HCV), since $70 \%$ to $90 \%$ of HIV-infected patients have infection markers passed by VHB (FARIAS et al, 2012).

RC: 66674

Available in: https://www.nucleodoconhecimento.com.br/health/viral-hepatitis 
The clinical diagnosis of viral hepatitis is based on signs and symptoms presented by the patient, and individuals who have the virus (s) may present with acute, chronic and even asymptomatic symptoms. In cases of acute hepatitis, the patient may experience malaise, fatigue, nausea, choluria (darkened urine), anorexia, jaundice and whitish colored stools. In the case of chronic hepatitis, individuals can sometimes be asymptomatic, but liver disorders may appear after a certain period, such as liver cirrhosis, liver fibrosis and even hepatocellular carcinoma (depending on the evolution, other organs may be compromised). The diagnosis occurs, mostly, in the chronic phase of the disease (mainly in hepatitis B and C). At the laboratory level, it is possible to detect markers for hepatitis, and the contents used for this process are oral fluids, blood, serum or plasma from the infected patient, using techniques called immunoassays. Such procedures aim to detect the antigen or antibodies and there are different types, which are: immunoenzymatic, luminescent and rapid tests. In addition to these, there is also the molecular test, based on the polymerase chain reaction (PCR) (BRASIL, 2018b and SBI, 2003).

Education is presented as one of the factors that are taken into consideration at an epidemiological level to understand the impact of hepatitis in Brazil. Regarding confirmed cases of viral hepatitis, it is noted that a large portion covers people with schooling from the fifth to the eighth grade of elementary school, and from 1999 to 2018 , among males, of the total number of confirmed cases, there were 21,844 that correspond to this profile (inferior only to the "ignored" category, using data from the 2019 Epidemiological Bulletin on Viral Hepatitis of 2019) (BRASIL, 2019).

\section{CONCLUSIONS}

Hepatitis represents a vast public health problem in Brazil, and factors such as the unequal distribution of health services, socioeconomic disparities and other issues contribute to this imbroglio.

Of those infected, a large portion is made up of male individuals, with the visible lower demand for health services an important factor for this finding. Because of this

RC: 66674

Available in: https://www.nucleodoconhecimento.com.br/health/viral-hepatitis 
issue, they tend to suffer more chronic afflictions due to the delay in seeking a health professional. Hemodialysis patients, sex workers and people who use injectable drugs are some of the main risk groups for infection by viruses that cause viral hepatitis. In addition, it was found that in the period from 1999 to 2018, a large portion of confirmed cases of hepatitis (21,844 cases) corresponded to individuals with incomplete schooling from the fifth to the eighth grade of elementary school.

Hepatitis $\mathrm{B}$ and $\mathrm{C}$ are the most common among viral hepatitis. In recent years, there has been a significant increase (greater than 90\%) in the transmission of hepatitis B through sex. The transmission of hepatitis $C$ through sexual intercourse is debated, and its potential for transmissibility through sexual intercourse is considered limited, therefore, it is not considered an STI.

One of the important and contributing factors to the rate of infection by the hepatitis viruses is their co-infection with HIV. About $70 \%$ to $90 \%$ of HIV seropositive patients have markers of previous HBV infection.

For the diagnosis of viral hepatitis to be made, clinical and laboratory criteria are taken into account. Signs and symptoms, such as jaundice, choluria, whitish colored stools, fatigue, malaise, nausea and others may present in the patient with hepatitis. However, there may also be asymptomatic cases, which contribute to the delay in diagnosis and the consequent chronicity of the disease. Laboratory tests (immunoassay, molecular test) must be performed to detect markers and determine the etiologic agent that causes the pathology.

\section{REFERENCES}

ALMEIDA, C. S. C.; MARTINS, L. C. Soroepidemiologia do vírus da hepatite C em cônjuges de portadores desse vírus. Revista Paranaense de Medicina, v. 29, n.1, p. 11-16, 2015.

RC: 66674

Available in: https://www.nucleodoconhecimento.com.br/health/viral-hepatitis 
BRASIL. Ministério da Saúde. Portal da Saúde. PRENVEnÇÃO-HEPATITES: HEPATITE D. Disponível em:< http://portalsaude.saude.gov.br/index.php/links-deinteresse/305-hepatites-virais/prevencao-hepatites/9124-hepatite-d> . 2014.

BRASIL. Ministério da Saúde. Portal da Saúde. PREnVEnÇÃO-HEPATITES: HEPATITE B. Disponível em:<http://portalsaude.saude.gov.br/index.php/links-deinteresse/305-hepatites-virais/prevencao-hepatites/9130-hepatite-b > . 2014a.

BRASIL, 2015. Ministério da Saúde. Boletim Epidemiológico Hepatites virais. Ano IV, n. 01, 2015.

BRASIL, 2018a. Ministério da Saúde. Boletim Epidemiológico Hepatites Virais. V. 49, 2018.

BRASIL, 2018b. Ministério da saúde. Manual técnico para o diagnóstico das hepatites virais. 2018.

BRASIL, 2019. Ministério da Saúde. Boletim Epidemiológico Hepatites Virais. V.50, 2019.

FARIAS, N.; SOUZA, I.; COELHO, D. M.; OLIVEIRA, U. B.; BINELLI, C. A. Coinfecção pelos vírus das hepatites $B$ ou $C$ e da imunodeficiência adquirida: estudo exploratório no estado de São Paulo, Brasil, 2007 a 2010. Epidemiol. Serv. Saúde, v. 21 , n. 3, p. 475-486, 2012.

FERREIRA, C. T.; SILVEIRA, T R. Hepatites virais: aspectos da epidemiologia e da prevenção. Rev. bras. epidemiol., v. 7, n. 4, p. 473-487, 2004 .

FERREIRA, A.R.; FAGUNDES, E.D.T.; QUEIROZ, T.C.N.; PIMENTA, J.R.; JÚNIOR, R.C. N.. Hepatites Virais A, B e C em crianças e adolescentes. Rev Med de Minas Gerais, (Supl 2): S46-S60, 2014.

RC: 66674

Available in: https://www.nucleodoconhecimento.com.br/health/viral-hepatitis 
FRANCISCO, P.M.S.B; DONALISIO, M.R; GABRIEL, F.J.O; BARROS, M.B.A. Vacinação contra hepatite $B$ em adolescentes residentes em Campinas, São Paulo, Brasil. REV BRAS EPIDEMIOL, 18(3): 552-567, JUL-SET 2015.

GOMES, R.; NASCIMENTO, E. F.; ARAÚJO, F. C. Por que os homens buscam menos os serviços de saúde do que as mulheres? As explicações de homens com baixa escolaridade e homens com ensino superior. Cad. Saúde Pública, v. 23, n.3, p. $565-574,2007$.

GUSMÃO, K.E et al. PERFIL CLÍNICO-EPIDEMIOLÓGICO DA HEPATITE C NA REGIÃO NORTE DO BRASIL ENTRE 2012 E 2015.Revistade Patologia do Tocantins, [S.I.], v. 4, n. 2, p. 41-45, jun. 2017.

LEITE, A.C.D. et al. . Avaliação das Internações Pela Hepatite Aguda B em Comparativo com a Aplicação de Doses da Vacina Contra Hbv, Na Região Norte. In: Luís Marcelo Aranha Camargo; Dionatas Ulises de Oliveira Meneguetti; Jader de Oliveira. (Org.). Atualidades em Medicina Tropical no Brasil: Educação em Saúde. 1ed.Rio Branco, Acre: Stricto Sensu Editora, 2020, p. 39-48.

MARGREITER, S. et al. Estudo de prevalêcia das hepatites virais b e c no município de palhoça-sc. Rev. Saíde Públ. Santa Cat., Florianópolis, v. 8, n. 2, p. 21-32, maio/ago. 2015.

MOCBEL, I.L.S.A. et al. CONHECIMENTO SOBRE HEPATITES A e E DOS ESTUDANTES DE UMA ESCOLA MUNICIPAL EM SANTARÉM - PA. Revista EM FOCO - Fundação Esperança/IESPES, [S.I.], v. 2, n. 24, p. 18-29, abr. 2016.

NUNES, H.M. et al. Soroprevalência da infecção pelos vírus das hepatites A B, C, D e E em município da região oeste do Estado do Pará, Brasil. Rev. Pan-Amaz. Saúde, Ananindeua, v. 7, n. 1, p. 55-62, mar. 2016.

SBI (SOCIEDADE BRASILEIRA DE INFECTOLOGIA). Boletim terapêutico de HIV/Aids, DTS e Hepatites Virais. Ano I, n. 4, 2003.

RC: 66674

Available in: https://www.nucleodoconhecimento.com.br/health/viral-hepatitis 
SILVA, C.M; VIANNA, G.S.P; SOARES, M.C.P; AMARAL, I.S.A.; MOIA, L.J.M.P. AVALIAÇÃO DO HEMOGRAMA EM PACIENTES TRATADOS PARA HEPATITE C1. Revista Paraense de Medicina - V.28 (2) abril-junho 2014.

Submitted: November, 2020.

Approved: November, 2020.

RC: 66674

Available in: https://www.nucleodoconhecimento.com.br/health/viral-hepatitis 